\title{
SEASONAL OCCURRENCE OF IBUPROFEN IN SEDIMENT, WATER, AND BIOTA IN RIVER OWENA AND OGBESE, AND ITS ECOLOGICAL RISK ASSESSMENT
}

\author{
Germaine, A. Ogunwole ${ }^{*}$, and Joseph, K. Saliu ${ }^{2}$
}

${ }^{1}$ Department of Biology, School of Science, Federal University of Technology, Akure. P.M.B 704, Ondo, Nigeria.

${ }^{2}$ Department of Zoology, Faculty of Science, University of Lagos, Akoka, Lagos, Nigeria.

Received $16^{\text {th }}$ November, 2019, Accepted $5^{\text {th }}$ March, 2020

DOI: 10.2478/ast-2020-0002

${ }^{*}$ Corresponding author

Germaine, A. Ogunwole E-mail: gaogunwole@futa.edu.ng

Tel: +2347031606728

\section{Abstract}

The volume of pharmaceuticals discharged into the environment increases daily as a consequence of human life. In the present study, the seasonal variation of ibuprofen in sediment, biota, water, and their exposure risk were investigated in River Owena and Ogbese, Nigeria. The high-performance liquid chromatography coupled to a mass spectrometer (HPLC-MS/MS) was used to analyze the samples after clean up and pre-concentration by solid-phase extraction. The mean concentration of IBU in the samples spanned a range of $1.75-2.75 \mu \mathrm{g} / \mathrm{g}$ in sediment, $0.01-$ $15.00 \mu \mathrm{g} / \mathrm{g}$ in fish, and $0.00002-0.005 \mu \mathrm{g} / \mathrm{ml}$ in water. The measurement of IBU in the sediment and water was significantly elevated in the dry season than the wet season, whereas the opposite was the case in biota. There was a significant interaction between season, media, and rivers with respect to IBU occurrence in the sampled rivers. The calculated bio-water accumulation factor (BWAF) was as high as 750,000 $\mu \mathrm{g} / \mathrm{g}$ in fish, proving IBU is extremely bio-accumulative. The ecotoxicological risk assessment for average and worst possible outcome showed that the risk quotient (RQ) for IBU present in the water was sufficient to cause toxicity to fish in both freshwater bodies. The potential bioavailability of IBU to aquatic fauna for prolonged periods spanning several months can result in its circling back into the food web afterward. The baseline info provided by this study in these freshwaters may provide valuable information for the implementation of safety limits for the management of IBU influx into the environment.

Keywords: Ibuprofen, Owena, Ogbese, Bioaccumulation, Water, Sediment, Biota, and risk assessment. 


\subsection{Introduction}

There has been a surge in the volume of legacy and emerging contaminants in the environment, such as pharmaceutical compounds utilized as prophylaxis, diagnosis, and treatment of diseases. As a result, the pharmaceutical industry is amongst the fastest developing sector globally (Mompelat et al., 2009). A considerable rise in the consumption of non-prescribed has been detected, a prominent category consist of the non-steroid anti-inflammatory drugs (NSAIDs), utilized in the remedy of pain, inflammation, and arthritic conditions (Sonowska et al., 2009). NSAIDs function via the suppression of the cyclooxygenase (COX) enzymes known to incite the biosynthesis of prostaglandins and thromboxane from arachidonic acid (Modi et al., 2012; Lucia et al., 2015).

Scientific research over the past two decades has shown that NSAIDs, like all pharmaceuticals, are ubiquitous in the environment, primarily via excretion in its parent form and metabolites through faeces or urine (Metcalfe et al., 2003; Kummerer, 2010), unabating wastewater discharges from drug factories, hospitals, agribusiness and fisheries, clustered homes and areas with people. The significant source of pharmaceuticals in wastewater, underground, and surface waters can also arise from the inappropriate disposal of unused and expired drugs, and terminal effluent wastewater (Sandor et al., 2012). Due to the molecular and physicochemical properties of NSAIDs, these drugs can persist in the aqueous environment (Akbar et al., 2015). Of all detected pharmaceuticals, the NSAID ibuprofen (IBU) was consistently detected at higher concentrations than other drugs in the effluents of wastewater treatment plants (WWTPs) (Lishman et al., 2006).

IBU (RS -2-[4-(2-methyl propyl)phenyl] propanoic acid), a nonselective NSAID, has a global annual production rate of several kilotons because it is among the most frequently prescribed and commonly used (Abraham and KI, 2005; Ali et al., 2009). It is also enlisted as one of the core medicines in the World Health Organization (WHO) "Essential Drugs List" as a result of its widespread application as an anti-inflammatory, antipyretic, and analgesic compound (Han et al., 2010). Due to its high rate of application in tandem with the drug pharmacokinetics (half-life, metabolism, faecal, and urinary excretion), IBU can build up to measurable levels in the ecosystem (Cleuvers, 2004).

IBU has been detected at varying concentrations in environmental samples, e.g., in wastewater from $37.99 \mu \mathrm{g} / \mathrm{L}$ in Nigeria (Lan et al., 2019), to $45 \mu \mathrm{g} / \mathrm{L}$ in Canada (Guerra et al. 2014), 703-1673 $\mu \mathrm{g} / \mathrm{L}$ in Pakistan, $221 \mu \mathrm{g} / \mathrm{L}$ in South Africa, and $5.78 \mu \mathrm{g} / \mathrm{L}$ in Belgium (Madikizela and Chimuka, 2016a; Ashfaq et al., 2017a; Żur et al., 2018). IBU has been detected in surface waters near releases from sewage effluents with a mean concentration of $0.02-79.45 \mu \mathrm{g} / \mathrm{L}$ (Nigeria), and within a range of 0.0002-5.04 $\mu \mathrm{g} / \mathrm{L}$ in Brazil, Canada, China, Germany, Italy, Sweden, Britain and the United States of America (Olarinmoye et al., 2016; Lan et al., 2019). A review by Żur et al., 2018, stated that IBU was recorded in receiving waters at a mean concentration range of $0.98-67 \mu \mathrm{g} / \mathrm{L}$ in Canada and Greece, $0.98 \mu \mathrm{g} / \mathrm{L}$ (Canada), 1.0 - 67 $\mu \mathrm{g} / \mathrm{L}$ (Greece), < 15 - $414 \mu \mathrm{g} / \mathrm{L}$ (Korea), 5.0 - $280 \mu \mathrm{g} / \mathrm{L}$ (Taiwan), ND $8.0 \mu \mathrm{g} / \mathrm{L}$ (France), and ND - $1417 \mu \mathrm{g} / \mathrm{L}$ (China) (Almeida et al., 2013; Luo et al., 2014).

According to Luo et al., (2014), the mean concentration of IBU detected in groundwater in Europe was $3 \mathrm{ng} / \mathrm{L}$, with a maximal concentration of $395 \mathrm{ng} / \mathrm{L}$. In soil, detected IBU concentrations ranged between 321 -

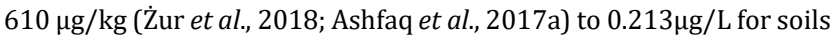
irrigated with wastewater containing pharmaceutical residues (Żur et al., 2018; Vazquez-Roig et al., 2012). Pharmaceutical products are typically formulated to cross biological membranes, and thus the rate of uptake and internal concentrations are imperative. Therefore, to fully understand the potential for pharmaceuticals to induce harm in the aquatic ecosystem, it is crucial to assess the broader occurrence of the bioavailable fraction in biota (invertebrates, fish, plants, and algae). The choice of fish (due to its high rank in the aquatic food web) provides a broader understanding of the overall health of the environment since they are capable of integrating contaminants and pollutants from lower trophic levels. The popular NSAIDs, IBU, diclofenac, and naproxen have all been shown to accumulate in fish (Lahti et al., 2011).

The potentially harmful impact of NSAIDS, together with their prevalent use and the potential for long-distance transport, makes it essential to monitor them in the various environmental matrice. In order to gain a proper insight into the transportation and fate of NSAIDS, the seasonal variation data of these compounds in various environmental media are essential. Recently, numerous studies have demonstrated the occurrence of pharmaceuticals in aquatic environments (Thomas et al., 2018; Anekwe et al., 2017). To the best of the authors' knowledge, none of such reports dwelled on the seasonal variation of IBU in various environmental matrices in subSaharan freshwaters in Africa has been published. Some of the published African reports focused more on wastewater and impacted surface water with pharmaceutical effluents, with little information on the bioaccumulation potential in biota and the environmental pollution caused by drugs on sediments and (Olarinmoye et al., 2016. 2010; Madikizela et al., 2017; Samuel et al., 2018).

Therefore, this investigation seeks to evaluate the seasonal variation of IBU in sediment, biota, and water in two major freshwater bodies (River Owena and Ogbese) in Nigeria, and to evaluate the ecological risk factor it portends for the ecosystem. 


\subsection{Experimental}

\section{The Study Area}

This investigation was conducted in River Ogbese (Figure 1: Longitudes $5^{\circ} 26^{\prime} \mathrm{E}$ to $6^{\circ} 34^{\prime} \mathrm{E}$ and latitudes $6^{\circ} 43^{\prime} \mathrm{N}$ to $7^{\circ} 17^{\prime} \mathrm{N}$ ), and River

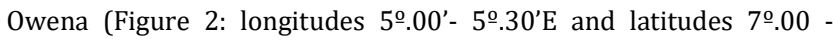
$7^{\circ} .30^{\prime} \mathrm{N}$ ). These two freshwater bodies are prominent in southwest Nigeria, with a reasonable number of the populace dependent on them as a source of food (artisanal fisheries), drinking water, aquaculture business, irrigation, laundry, waste disposal and for industrial purposes on a large scale. The Owena river houses a dam, covering an appropriate surface area of $7.8 \mathrm{sq} \mathrm{km}$ and with the capacity to feed $60,000 \mathrm{~m} 3 /$ day to the water treatment plant built beside the dam.

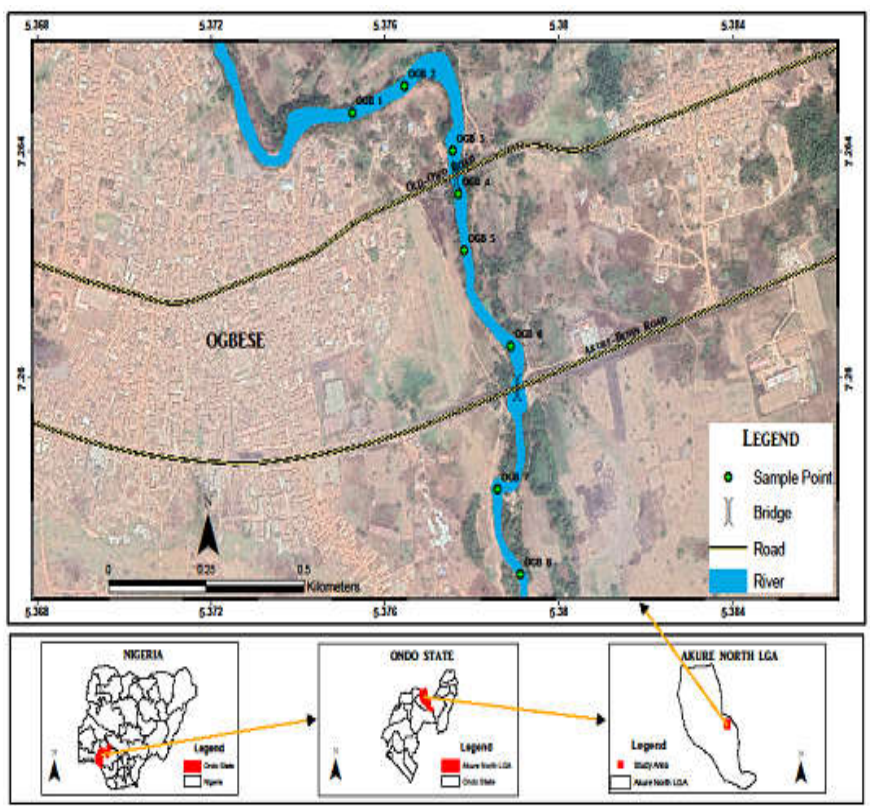

Figure 1: Showing River Ogbese Sampling Locations

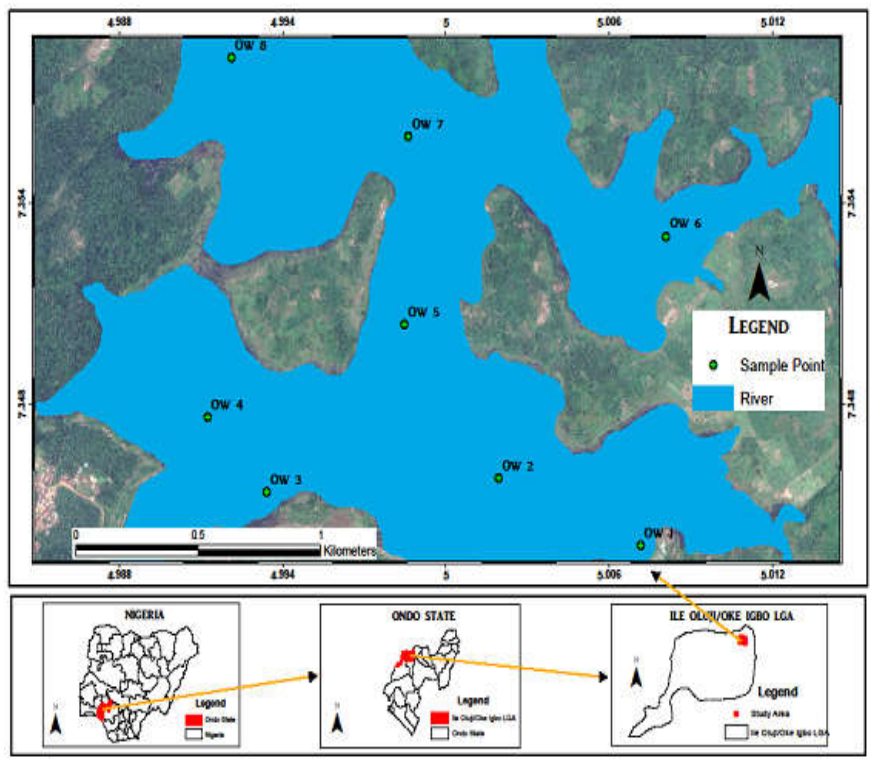

Figure 2: Showing River Owena Sampling Locations

\section{Chemicals and materials}

Analytical grade IBU, with a purity of $98 \%$ or higher, was purchased from Bristol scientific, an authorized distributor of Sigma-Aldrich in Nigeria. Stock standard solutions of pharmaceuticals were prepared in methanol (HPLC grade, Merck) at $100 \mathrm{mg} / \mathrm{L}$ and were stored at $-20^{\circ} \mathrm{C}$. Working standard solutions were daily prepared from the stock standard solution using methanol as solvent and kept at $4{ }^{\circ} \mathrm{C}$ before analysis. Amber glassware was used to prevent light degradation of pharmaceuticals.

All the solvents used, methanol, acetonitrile, Trifluoroacetic acid, and acetone, were of HPLC grade and were all purchased from the same source as IBU. Oasis HLB ( $6 \mathrm{~mL}, 200 \mathrm{~g}$ ) was used to perform solidphase extraction (SPE).

\section{Collection of Samples, Processing, and Analysis}

Between March 2018 and February 2019, composite sediment and water samples were collected in the morning from the designated sampling sites into $2 \mathrm{~L}$ amber coloured bottles and aluminum foil, respectively, ensuring that there was very minimal contamination of the sampling equipment and samples before, during, and after the sampling.

Water was sampled using the dip collection method, which involved decapping the bottles and dipping them below the surface $(0-20 \mathrm{~cm})$ at each sampling location until it was filled up to the shoulder to provide sufficient room for expansion during freezing. A few drops of concentrated hydrochloric acid (HCL) was added to adjust the $\mathrm{pH}$ of the sample to $<2$, in order to decrease the activity of microbes, precipitation, and sorption losses to container walls (Ferhan and Ulan, 2017). For the sediment, Grab samples at a depth of $0-10 \mathrm{~cm}$ in all sampling sites were collected with the aid of depth samplers. Collected samples were allowed to drain and wrapped in aluminum foil. Following collection, water and sediment samples were placed in coolers with ice packs, transferred to the laboratory, and preserved at $4^{\circ} \mathrm{C}$ until further analysis. Live samples of two species of fish, Clarias gariepinus (Catfish) and Tilapia zilli (Tilapia spp) were obtained directly from fresh landings of fishers from the river bodies. All fish samples were wrapped in well-labeled aluminum foil (individual wrapping) and equally stored, transported, and preserved like the water and sediment sample for further analysis.

\section{Sample pretreatment}

\section{Water}

The frozen water sample was thawed and then sieved with cotton wool and Whatman filter paper dis $18 \mathrm{~cm}(0.45 \mu \mathrm{m})$ to eliminate particulates, samples were preserved in a frozen state before the solid phase extraction (SPE). Extraction was conducted using Oasis HLB cartridge ( $6 \mathrm{ml}, 200 \mathrm{mg}$ ); cartridges were activated and conditioned with $6 \mathrm{~mL}$ methanol and $6 \mathrm{~mL}$ water, respectively. Precisely $500 \mathrm{~mL}$ of the sample was transferred into the cartridges and rinsed with $5 \% \mathrm{v} / \mathrm{v}$ methanol in water. Cartridges were eluted with $3 \mathrm{~mL}$ x 2 methanol and subsequently evaporated using nitrogen gas $\left(\mathrm{N}_{2}\right)$ and reconstituted with $0.5 \mathrm{~mL}$ of methanol before it was transferred to vials for HP-LC analysis using standards methods adopted from the USEPA (2011). 


\section{Sediment}

Collected samples were air-dried at ambient temperature and away from plastic materials. $20 \mathrm{~mL}$ of Dichloromethane-Methanol (DCM) and methanol were used as extraction solvents for $2 \mathrm{~g}$ of the dry sample, and it was then sonicated for $30 \mathrm{mins}$ at $50^{\circ} \mathrm{C}$ in an ultrasonic bath. The solvents were carefully decanted into a $100 \mathrm{~mL}$ beaker and evaporated to dryness using $\mathrm{N}_{2}$. The sample was reconstituted with 2 $\mathrm{mL}$ methanol and makeup to $100 \mathrm{~mL}$ in a $100 \mathrm{~mL}$ volumetric flask. In the Solid-phase extraction (SPE), cartridges were primed and activated with $6 \mathrm{~mL}$ water and $6 \mathrm{~mL}$ methanol, respectively. $2 \mathrm{~g}$ of the sample was loaded into the cartridges and washed with $5 \% \mathrm{v} / \mathrm{v}$ methanol in water. Cartridges were eluted with $3 \mathrm{~mL} \times 2$ methanol and subsequently evaporated using $\mathrm{N}_{2}$ and reconstituted with $0.5 \mathrm{~mL}$ of methanol before it was transferred to vials for HP-LC analysis using standards methods adopted from the USEPA (2011).

\section{Biota}

Tissues from sampled fish were collected and homogenized using a blender and stored in a freezer before extraction. The homogenized fish tissues were thawed, and a known weight in duplicate was combined with an extraction solvent (0.1M acetic / methanol) (2 g:10 $\mathrm{mL}$ ). The duplicate samples were sonicated for 30 minutes, transferred to a centrifuge tube, and centrifuged at 4,000 rpm for $10 \mathrm{mins}$, and the supernatant was collected. The supernatants were pooled and evaporated using $\mathrm{N}_{2}$ at $45^{\circ} \mathrm{C}$ and reconstituted with $0.5 \mathrm{~mL}$ of methanol and made up to $100 \mathrm{ml}$ with water. In the SPE, cartridges were activated and conditioned with $6 \mathrm{~mL}$ methanol and $6 \mathrm{~mL}$ water respectively. $100 \mathrm{~mL}$ of the sample was transferred into the cartridges and washed with $5 \% \mathrm{v} / \mathrm{v}$ methanol in water. Cartridges were eluted with $3 \mathrm{~mL}$ x 2 methanol and subsequently evaporated using $\mathrm{N}_{2}$ and reconstituted with $0.5 \mathrm{~mL}$ of methanol before it was transferred to vials for HP-LC analysis using methods as described by Liu et al., (2018) and Huerta et al., (2013).

\section{Analytical Procedure}

The qualitative and quantitative analysis of IBU was conducted utilizing a high-performance liquid chromatography (HP-LC). Analytes were separated with the aid of an Agilent HPLC 1100 fitted a thermostated column compartment, an auto liquid sampler, a binary pump, a multi-wavelength detector, and a degasser. Samples were analyzed under LC-tandem MS conditions based on the detailed description of Gentili et al., 2012. In brief, the IBU was separated through a reversed-phase ion-pair chromatography on an XTerra-MS C18 $(150 \times 4.6 \mathrm{~mm}$ I.D.; $5 \mu \mathrm{m})$ (Waters, Milano, Italy), using a mixture of acetonitrile: methanol (50:50, v/v) as eluent $A$ and water as eluent $\mathrm{B}$; dibutyl amine $(0.2 \mathrm{mM})$ was added to both phases as an ion-pair agent.

\section{Risk Assessment}

The environmental risk associated with IBU was evaluated by calculating the risk quotient values (RQ) obtained by dividing the maximum measured environmental concentrations (MEC) by the corresponding predicted no-effect concentrations (PNEC) (Equation 1). PNEC values were estimated for Vibrio fischeri (bacteria), algae, Daphnia magna, and fish (Clarias gariepinus) from published acute toxicity data. Precisely, by dividing $\mathrm{EC}_{50}$ values by an arbitrary safety factor of 1000, PNEC was derived to capture the deduction from inter and intra-species sensitivity and variability (Hernando et al., 2006; Sanderson et al., 2004) (Equation 2).

$\begin{array}{lll}\text { RQ } 1 / 4 & \text { MEC } & \\ \text { PNEC } & \text { Eqn. } 1\end{array}$

PNEC was calculated as:

PNEC $\quad 1 / 4 \frac{\mathrm{EC}_{50} \text { or } \mathrm{LC}_{50}}{\mathrm{AF}} \quad$ Eqn. 2

The values of $\mathrm{EC}_{50}$ deployed in this investigation were retrieved from the literature and are summarized in table 3 . It is pertinent to state that when more than one $\mathrm{EC}_{50}$ value was discovered, the lowest values were taken into consideration. The risk to biota was grouped into three categories: Low risk (RQ below 0.1 ), moderate risk (RQ 0.1 to below 1), and high risk ( $\geq 1$ ) (de Souza et al., 2009).

\section{Statistical Analysis}

The experimental data were analyzed using the SPSS statistical package (Version 25). Mean Concentrations of the compound detected in water, sediment, as well as biota samples in both rivers, were compared using a one-way analysis of variance (ANOVA) to separate the means. A generalized linear model (GLM) analysis was conducted to evaluate the interaction between media (sediment, water, and biota), season (wet and dry), and freshwater bodies (Owena and Ogbese). Significant differences were determined at $p<0.05$.

\subsection{Results and Discussion}

\section{Environmental Assessment of IBU in Water, Sediments, and Biota} in River Owena and Ogbese, Ondo State

The seasonal concentration of IBU in sediment, water, and biota in river Ogbese and Owena are presented in table 1.

\section{Sediment}

In both freshwater bodies, the mean level of IBU was significantly higher $(p<0.05)$ in the dry season $(1.89-2.74 \mu \mathrm{g} / \mathrm{g})$, when compared to the wet season $(1.75-2.52 \mu \mathrm{g} / \mathrm{g})$. The highest mean concentration of IBU $(2.74 \mu \mathrm{g} / \mathrm{g})$ in the sediment was recorded in River Owena (dry), while the lowest mean level of $1.75 \mu \mathrm{g} / \mathrm{g}$ was recorded in River Ogbese (Wet). Sediments typically act as the ultimate sink for pollutants released into the environment (Malferrari et al., 2009). The mean level of IBU in sediments seasonally varied in both rivers, with the dry season having a statistically high level than the wet season (Table 1). The seasonal variations of IBU in sediment were potentially influenced by limiting agents such as dissolved organic matter, $\mathrm{pH}$, temperature, and salinity. In this study, the relatively high concentrations of IBU in the dry season could be attributed to an increase in salinity due to the "salting out" effect, acting in tandem to an acidified sediment, which greatly enhanced its sorption to sediment (Oh et al., 2016). The high sediment concentration of IBU in both rivers may be ascribed to the high consumption rate of the drug either through prescription and over the counter purchases which eventually find their way into the environment via metabolic excretion or inappropriate disposal of unwanted and expired drugs (common in a developing economy like Nigeria) 


\section{Water}

In water, the mean concentration of IBU in the dry season $(0.003-$ $0.005 \mu \mathrm{g} / \mathrm{ml})$ in both rivers were significantly greater $(p<0.05)$ than levels detected in the wet season $(0.00002-0.00003 \mu \mathrm{g} / \mathrm{ml})$. The highest mean concentration of IBU $(0.05 \mu \mathrm{g} / \mathrm{ml})$ in the water was recorded in River Owena (dry), while the lowest mean level of 0.00002 $\mu \mathrm{g} / \mathrm{ml}$ was recorded in River Owena (Wet). At low $\mathrm{pH}$, weak acids like IBU with a pKa of 4.9 exist in a unionized form, which increases its hydrophobicity (William \& Randy, 1997), and consequently increases its permeability to a biological membrane (Pranitha and Lakshmi, 2018). In this study, this pattern was corroborated entirely with a significantly high level of IBU in the dry season than wet season, and the corresponding significant high levels of IBU in biota in the wet season when compared to the dry season. An indication that the $\mathrm{pH}$ of the freshwater bodies in the wet season may be slightly acidic, likely influenced by climatic factors such as high precipitation of acidic rain, runoff via strongly acidic soils the study area is known for into the freshwaters (Fasina et al., 2015). Fasina et al., 2015, stated that soils of Ondo and Fagbo are significantly acidic (4.50) to moderately acidic (5.70), containing a lot of iron-manganese concretions, quartz stones, and gravels. The mean level of IBU in both fresh surface water bodies in this study was lower when compared to literature values from the basin of River Nairobi in Kenya (K'oreje et al., 2012), and Umgeli River, South Africa (Solomon et al., 2015). The significant variance in the concentration of IBU in both rivers could be a function of size, wet precipitation, topography, flow rate, and the proximity and volume of human activities.

\section{Biota}

In contrast to sediment and water, the mean level of IBU in biota in the wet season $(0.44-15.00 \mu \mathrm{g} / \mathrm{g})$ in both rivers was significantly higher $(p<0.05)$ than levels detected in the dry season $(0.01-0.24 \mu \mathrm{g} / \mathrm{g})$. The highest mean concentration of IBU $(15.00 \mu \mathrm{g} / \mathrm{g})$ in the biota was recorded in River Owena (wet), while the lowest mean level of 0.01 $\mu \mathrm{g} / \mathrm{g}$ was recorded in River Ogbese (dry). The mean bio-water accumulation factor (BWAF) of IBU in biota in both rivers was severe in the wet season $(14.666 .67-750,000 \mu \mathrm{g} / \mathrm{g})$ when compared to the dry season $(3.33-48 \mu \mathrm{g} / \mathrm{g})$. The highest BWAF was recorded river Owena (wet), closely followed by Ogbese (wet), > Owena (dry), and Ogbese (wet). Numerous invertebrates and non-target vertebrates share drug targets with humans (Gunnarsson et al., 2008); thus, the high accumulation of IBU may induce the therapeutic effects of the drug in biota. The BWAF in both rivers showed IBU to be extremely bioaccumulative, having crossed the threshold limit of 5,000 for aquatic organisms (Arnot and Gobas, 2006). The measured BWAF in River Owena during the wet season was 7.8 times greater than the values reported by Lagesson et al., 2016. They measured a BAF value of 96,000 for hydroxyzine in the Planorbidae, a freshwater snail that was exposed to a cocktail of pharmaceuticals in a semi-natural pond at Umea, Sweden. The extreme BWAF values could be as a consequence of the semi-persistent nature of the compound in the river bodies, the half-life of IBU in the environment is about 64 days which exceeds the United Nations Environmental Programme (UNEP) threshold limit at
60 days to define a chemical as persistent in the aquatic environment (Araujo et al., 2014). The enormous bioaccumulation of IBU may also give rise to unexpected effects such as endocrine disruption, compulsive feeding, boldness, and aggression, not related to the desired therapeutic effects (Klimaszyk and Rzymski, 2019).

Table 1: Seasonal Assessment of IBU in Water, Sediments and Fish Tissue in River Owena and Ogbese, Nigeria

\begin{tabular}{|c|c|c|c|c|c|}
\hline River & Season & $\begin{array}{l}\text { Sediment } \\
{[\mu \mathrm{g} / \mathrm{g}]}\end{array}$ & Water $[\mu \mathrm{g} / \mathrm{ml}]$ & Biota $[\mu \mathrm{g} / \mathrm{g}]$ & $\begin{array}{l}\text { BWAF } \\
{[\mu \mathrm{g} / \mathrm{g}]}\end{array}$ \\
\hline & & $\mathrm{M} \pm \mathrm{SE}$ & $\mathrm{M} \pm \mathrm{SE}$ & $\mathrm{M} \pm \mathrm{SE}$ & \\
\hline \multirow[t]{2}{*}{ Owena } & Wet & $2.52 \pm 0.03^{f}$ & $0.00002 \pm 0.11^{\mathrm{d}}$ & $15.00 \pm 0.10 \mathrm{~g}$ & 750,000 \\
\hline & Dry & $2.74 \pm 0.07 \mathrm{~g}$ & $0.005 \pm 0.06 \mathrm{e}$ & $0.24 \pm 0.05^{e}$ & 48 \\
\hline \multirow[t]{2}{*}{ Ogbese } & Wet & $1.75 \pm 0.01^{\mathrm{d}}$ & $0.00003 \pm 0.17 \mathrm{~d}$ & $0.44 \pm 0.08^{\mathrm{f}}$ & $14,666.67$ \\
\hline & Dry & $1.89 \pm 0.02^{\mathrm{e}}$ & $0.003 \pm 0.02^{\mathrm{e}}$ & $0.01 \pm 0.16^{\mathrm{d}}$ & 3.33 \\
\hline
\end{tabular}

Note: Means values with the same superscript alphabets in the same column are not significantly different $(p<0.05)$ from each other

\section{Interaction of Media (Sediment, water, and fish), Rivers (Owena and Ogbese) and Seasons (Wet and Dry), and their Influence on IBU of Concentration}

A generalized linear model (GLM) analysis was conducted to examine the effect of medium (M), season (S), and river (R) on IBU concentration are presented in table 2 . All effects were statistically relevant at the 0.05 level. There was a significant interaction between the effects of medium and season, $\mathrm{F}(2,60)=8457.02, \mathrm{p}=0.000$, medium and river, $\mathrm{F}(2,60)=7909.64, \mathrm{p}=0.000$; season and river, $\mathrm{F}$ $(1,60), 9156.64, \mathrm{p}=0.000$, medium, season, and river, $\mathrm{F}(2,60)=$ 9300.36, $p=0.000$ on IBU concentration. The simple main effects analysis showed that the size of the river and season greatly influenced the dilution, solubility, and bioavailability of IBU to bioaccumulate in biota $(\mathrm{p}=.000)$.

The significant interaction $(\mathrm{p}<0.000)$ between season, medium, and river concerning IBU detection in both water bodies can mainly be attributed to acidic soil type (Fasina et al., 2015), and a high incidence and volume of acid rain. Ondo State is located along the Niger delta belt in Nigeria, a region that plays host to international oil exploration companies, with an attendant high natural gas flaring rate of 17.2 billion $\mathrm{m} 3$ per year as a bye product (Anslem, 2013). These flares emit a high volume of atmospheric contaminants such as oxides of Carbon, Sulphur, and Nitrogen $\left(\mathrm{CO}_{2}, \mathrm{SO}_{2}, \mathrm{NO}_{2}\right)$, which are precursors of acid rain. Thus, exposing the Niger delta area to regular incidences of acid rain with recorded $\mathrm{pH}$ ranging from 4.70 - 5.23 (Nduka et al., 2013; Efe and Mogborukor, 2012). 
Table 2: Interaction of Media (Sediment, water and fish), Rivers (Owena and Ogbese) and Seasons (Wet and Dry) and their Influence on IBU Concentration.

\begin{tabular}{llllll}
\hline Source & df & MS & F & $p$ & Effect Size \\
\hline Medium & 2 & 92.80 & 7437.09 & .000 & .995 \\
Season & 1 & 97.40 & 7806.07 & .000 & .992 \\
River & 1 & 134.76 & 10800.18 & .000 & .994 \\
MxS & 2 & 105.52 & 8457.02 & .000 & .997 \\
MxR & 2 & 98.69 & 7909.64 & .000 & .992 \\
SxR & 1 & 114.25 & 9156.64 & .000 & .991 \\
SxMx R & 2 & 116.05 & 9300.36 & .000 & .996 \\
Error & 60 & 2.18 & & & \\
Corrected Total & 35 & & & &
\end{tabular}

Note: $-\mathrm{S}=$ Season, $\mathrm{R}=$ River, $\mathrm{M}=$ Medium, $\mathrm{MS}=$ Mean squares

Table 3: Ecological Risk Assessment of IBU Using PNEC values Calculated from Ecotoxicological Studies Reported in The Literature and RQ Values for Water

\begin{tabular}{|c|c|c|c|c|c|c|}
\hline $\begin{array}{l}\text { Pharmaceutical } \\
\text { compound }\end{array}$ & Species & $\begin{array}{l}\mathrm{EC}_{50} \\
(\mathrm{mg} / \mathrm{L})\end{array}$ & $\begin{array}{l}\text { PNEC } \\
(\mu \mathrm{g} / \mathrm{mL})\end{array}$ & Reference & River & $\begin{array}{l}\text { Risk quotients (RQ) } \\
\text { for Water }\end{array}$ \\
\hline \multirow[t]{4}{*}{ IBP } & $\begin{array}{l}\text { Vibrio fischeri } \\
\text { (bacteria) }\end{array}$ & 37.5 & 0.038 & $\begin{array}{l}\text { (Camacho-Muñoz et } \\
\text { al. 2010) }\end{array}$ & $\begin{array}{l}\text { Owena } \\
\text { Ogbese }\end{array}$ & $\begin{array}{l}0.13 \\
0.08\end{array}$ \\
\hline & Algae & 5.7 & 0.006 & (Paíga et al. 2013) & $\begin{array}{l}\text { Owena } \\
\text { Ogbese }\end{array}$ & $\begin{array}{l}0.83 \\
0.50\end{array}$ \\
\hline & Daphnia magna & 9.06 & 0.009 & (Jones et al. 2002) & $\begin{array}{l}\text { Owena } \\
\text { Ogbese }\end{array}$ & $\begin{array}{l}0.56 \\
0.33\end{array}$ \\
\hline & Fish & 0.38 & 0.0003 & (Ogueji et al. 2017) & $\begin{array}{l}\text { Owena } \\
\text { Ogbese }\end{array}$ & $\begin{array}{l}16.67 \\
10.00\end{array}$ \\
\hline
\end{tabular}

\section{Risk assessment}

The risk quotient (RQ) values for ecological risk due to IBU in both rivers are presented in table 3 . The $\mathrm{RQs}$ for freshwater organisms except for fish $(10.00$ - 16.67), were generally lower than 1 (0.08 0.83 ), implying no harm is expected to occur in these aquatic animals. The high RQ estimated for fish in both rivers suggest high acute/chronic toxicity risk to fish populations. The calculated RQ values for IBU did not seem to pose any risk for bacteria, algae, and daphnia magna, this was consistent with studies by Eslami et al., 2015 and Pravin et al., 2018, they reported that NSAIDs such as IBU, naproxen (NPX), diclofenac (DIC), and indomethacin (IDM) did not pose any risk to bacteria, algae, and daphnia magna. However, the high $\mathrm{RQ}$ values for IBU on fish in both rivers is an implication of the significant number of drug target orthologs in fish (Gunnarsson et al., 2019). Gunnarsson et al., (2019) reported that $90 \%$ of all human drug targets had orthologues in zebrafish (D. rerio), $64 \%$ of the targets had orthologues in the water flea (D. pulex), and $34 \%$ in the green algae (Chlamydomonas reinhardtii). A study by Nesbitt (2011) demonstrated that at a concentration of $100 \mathrm{ng} / \mathrm{L}$, IBU and NPX induced a decrease in the rate of egg fertilization which can diminish spawning activities and fecundity, consequently leading to a decline in fish populations.

\section{Conclusion}

This study has confirmed the presence of IBU in sediment, biota, and water of freshwater bodies in Ondo State, Nigeria. The findings established that IBU is seemingly persistent in both sediment and water, with a high capacity to bioaccumulate in fish. The variation of the compound in various matrices established that season had a significant impact on its sorption, solubility, and bioavailability status. IBU in water posed a severe ecological risk to fish in both rivers, with $\mathrm{RQ}$ values as high as 16 . The environmental concentration of IBU in these freshwater bodies represents a high risk to impact fish populations negatively. Due to the high likelihood of IBU to remain and greatly bioaccumulate in aquatic organisms, it is recommended that more comprehensive monitoring campaigns in freshwater bodies be implemented, especially in areas with high anthropogenic activities to prevent deterioration of aquatic life.

\section{Acknowledgements}

We wish to thank the Laboratory for Interdisciplinary Statistical Analysis (LISA), of the Federal University of Technology, Akure for their immense statistical tutoring and guidance that facilitated the validity of this study. 


\section{Conflict of interest}

There is no conflict of interest with this manuscript.

\author{
Authors Contribution \\ Conception: GAO \\ Design: GAO and JKS \\ Execution: GAO \\ Interpretation: $\mathrm{GAO}$ and JKS \\ Writing the paper: GAO \\ Proofreading the paper: JKS
}

\section{References}

Abrahm, P. and KI, K. D. (2005). Nitro-argenine methyl ester, a nonselective inhibitor of nitric oxide synthase reduces IBU-induced gastric mucosal injury in the rat, Digestive Diseases, 50 (9); 1632-1640.

Akbar, E., Mostafa, M., Amini, A. R. Y., Noushin, R., A., Anoushiravan, M., Simin, N., Ehsan, P. and Anvar, A. (2015). Occurrence of non-steroidal anti-inflammatory drugs in Tehran source water, municipal and hospital wastewaters, and their ecotoxicological risk assessment, Environmental Monitoring Assessment, 187;734.

Alessandra, G., Fulvia, C., Simona, B., Lucia, M. R., Roberta, C. and Alessandro, V. (2012). Development and validation of two multiresidue liquid chromatography tandem mass spectrometry methods based on a versatile extraction procedure for isolating nonsteroidal anti-inflammatory drugs from bovine milk and muscle tissue, Analytical and Bioanalytical Chemistry, 404; 1375-1388.

Ali, I., Singh, P., Aboul-Enein, H. Y. and Sharma, B. (2009). Chiral analysis of ibuprofen residues in water and sediment, Analytical Letters, 42 (12); 1747-1760.

Anekwe, J. E., Mohamed, Abou-Elwafa, A. and Stuart, H. (2017). Pharmaceuticals and personal care products (PPCPs) in the freshwater aquatic environment, Emerging Contaminants, 3; 1-16.

Araujo, L., Troconis, M.E., Espina, M.B. and Prieto, A. (2014). Persistence of IBU, Ketoprofen, Diclofenac and Clofibric Acid in Natural Waters, Journal of Environment and Human, 1 (2); 32-38

Arnot, J.A. and Gobas, F.A. (2006). A review of bioconcentration factor (BCF) and bioaccumulation factor (BAF) assessments for organic chemicals in aquatic organisms, Environmental Review, 14; 257-297.

Camacho-Muñoz, D., Martín, J., Santos, J. L., Aparicio, I. and Alonso, E. (2010). Occurrence, temporal evolution and risk assessment of pharmaceutically active compounds in Doñana Park (Spain), Journal of Hazardous Materials, 183(1-3); 602-608.

De Souza, S.M.L., Vasconcelos, E.C., Dziedzic, M. and de Oliveira, C.M.R (2009). Environmental risk assessment of antibiotics: an intensive care unit analysis, Chemosphere, 77; 962-967.

Fasina, A.S., Raji, A., Oluwatosin, G.A., Omoju, O.J. and Oluwadare, D.A. (2015). Properties, Genesis, Classification, Capability and Sustainable Management of Soils from South-Western Nigeria, International
Journal of Soil Science, 10; 142-152.

Ferhan, Ç. and Ulaş, T. (2017). Hazardous Pollutants in Biological Treatment Systems, in: Fundamentals and a Guide to Experimental Research, IWA Publishing, Pp 81 - 85.

Gunnarsson, L, Jauhiainen, A., Kristiansson, E., Nerman, O. and Larsson, D. G. (2008). Evolutionary conservation of human drug targets in organisms used for environmental risk assessments. Environmental Science \& Technology.2 (15):5807-13

Gunnarsson, L., Jason, R. S., Bas, V., Stewart, F. O., Erik, K., Luigi, M., Tobias, Ö., Kathryn, H., Dean, L., Becky, M. and Charles, R. T. (2019). Pharmacology beyond the patient - The environmental risks of human drugs. Environment International, 129; 320-332.

Halimeh, A. S. S. (2012). Fate of Amoxicillin, IBU, and Caffeine in Soil and Ground Water Using Soil Columns (Doctoral dissertation, AnNajah National University, Nablus, West Bank, Palestinian Territories), Retrieved from https://www.researchgate.net/publication/273562 880

Han, S., Choi, K., Kim, J., Ji, K., Kim, S., Ahn, B., Yun, J., Choi, K., Khim, J. S., Zhang, X. and Giesy, J. P. (2010). Endocrine disruption and consequences of chronic exposure to ibuprofen in Japanese medaka (Oryzias latipes) and freshwater cladocerans Daphnia magna and Moina macrocopa, Aquatic Toxicology, 98; 256-264.

Huerta, B., Jakimska, A., Gros, M., Rodríguez-Mozaz, S. and Barceló D. (2013). Analysis of multi-class pharmaceuticals in fish tissues by ultra-high-performance liquid chromatography-tandem mass spectrometry. Journal of Chromatography A, 1288; 63-72.

Joanna, Ż., Artur, P., Ariel, M., Katarzyna, H., Danuta, W. and Urszula, G. (2018). Organic micropollutants paracetamol and ibuprofen-toxicity, biodegradation, and genetic background of their utilization by bacteria, Environmental Science and Pollution Research, 25; 21498.

Jones, O. A. H., Voulvoulis, N. and Lester, J. N. (2002). Aquatic environmental assessment of the top 25 English prescription pharmaceuticals. Water Research, 36 (20), 5013-5022.

Klimaszyk, P. and Rzymski, P. (2018) Water and Aquatic Fauna on Drugs: What are the Impacts of Pharmaceutical Pollution? In: Zelenakova M. (eds) Water Management and the Environment: Case Studies. WINEC 2017. Water Science and Technology Library, vol 86. Springer, Cham

K'oreje, K.O., Kristof, D., Patrick, D.W., Leendert, V., J. D. and Herman, V.L. (2012). From multi-residue screening to target analysis of pharmaceuticals in water: Development of a new approach based on magnetic sector mass spectrometry and application in the Nairobi River basin, Kenya, Science of The Total Environment, 437; 153-164

Kümmerer, K. (2010). Pharmaceuticals in the environment, Annual Review of Environment and Resources, 35; 57-75.

Lagesson, A., Fahlman, J., Brodina, T., Fick, J., Jonsson, M., Byström, P. and Klaminder, J. (2016). Bioaccumulation of five pharmaceuticals at 
multiple trophic levels in an aquatic food web - Insights from a field experiment. Science of the Total Environment, 568; 208-215.

Lahti, M., Brozinski, J. M., Jylhä, A. and Oikari, A. (2011). Uptake from water, biotransformation, and biliary excretion of pharmaceuticals by rainbow trout, Environmental Toxicology and Chemistry, 30;14031411.

Lawrence, M. M., Nikita, T. T. and Luke, C. (2017). Status of pharmaceuticals in African water bodies: Occurrence, removal and analytical methods, Journal of Environmental Management, 193; 211 220

Lishman, L., Smyth, S. A., Sarafin, K., Kleywegt, S., Toito, J., Peart, T., Lee, B., Servos, M., Beland, M. and Seto, P. (2006). Occurrence and reductions of pharmaceuticals and personal care products and estrogens by municipal wastewater treatment plants in Ontario, Canada. Science of the Total Environment, 367; 544-558.

Liu, Y. Y, Hu, X. L., Bao, Y. F. and Yin, D. Q. (2018). Simultaneous determination of 29 pharmaceuticals in fish muscle and plasma by ultrasonic extraction followed by SPE-UHPLC-MS/MS, Journal of Separation Science, 41: 2139- 2150.

Lucia, M. R., Alessandra, G., Fulvia, C., Roberta, C. and Virginia, P. (2015). Occurrence of non-steroidal anti-inflammatory drugs in surface waters of Central Italy by liquid chromatography-tandem mass spectrometry, International Journal of Environmental Analytical Chemistry, Pages; 685-697

Madikizela, L. M. and Chimuka, L. (2016a). Determination of IBU, naproxen and diclofenac in aqueous samples using a multi-template molecularly imprinted polymer as selective adsorbent for solid-phase extraction, Journal of Pharmaceutical and Biomedical Analysis, 128; 210-215.

Malferrari, D., Brigatti, M.F., Laurora, A. and Pini, S. (2009). Heavy metals in sediments from canals for water supplying and drainage: mobilization and control strategies, Journal of Hazardous Materials, 161; 723-729.

Michael, C. (2004). Mixture toxicity of the anti-inflammatory drugs diclofenac, IBU, naproxen, and acetylsalicylic acid. Ecotoxicology and Environmental Safety, 59; 309-315.

Modi, C. M., Mody, S. K., Patel, H. B., Dudhatra, G.B., Avinash, K. and Madhavi, A. (2012). Toxicopathological overview of analgesic and antiinflammatory drugs in animals, Journal of Applied Pharmaceutical Science, 02 (01); 149-157.

Mompelat, S., Le Bot, B. and Thomas, O. (2009). Occurrence and fate of pharmaceutical products and by-products, from resource to drinking water, Environment International, 35; 803-814.

Monika, D. J., (2015). Biomonitoring of Wild Fish to Assess Chemical Pollution in English Rivers - An Application of a Fish Tissue Archive (Doctoral dissertation, Lancaster University, Lancaster, United Kingdom). Retrieved from https://pdfs.semanticscholar.org/ac60/
Nesbitt, R. (2011). Effects of Chronic Exposure to IBU and Naproxen on Florida Flagfish (Jordanella Floridae) over One Complete Life-cycle. Master's thesis. University of Ontario Institute of Technology, Oshawa, Canada. https://ir.libraryDcuoit.ca/bitstream/10155/176/1/Nesbitt _Richard.pdf (Accessed 5 January 2016).

Ogueji, E.O., Nwani, C.D., Iheanacho, S.C., Mbah, C.E., Okeke, C.O. and Yaji, A. (2017). Acute toxicity effects of IBU on behavior and haematological parameters of African catfish Clarias gariepinus (Burchell, 1822), African Journal of Aquatic Science, 43:3; 293-303.

Oh, S., Shin, W. S., Kim, H. T. (2016). Effects of pH, dissolved organic matter, and salinity on IBU sorption on sediment, Environmental Science and Pollution Research, 23; 22882-22889.

Oluwatosin, O., Adekunle, B., Obih, U. and Arne, H. (2016). Quantification of pharmaceutical residues in wastewater impacted surface waters and sewage sludge from Lagos, Nigeria, Journal of Environmental Chemistry and Ecotoxicology, 8 (3); 14-24.

Paíga, P., Santos, L. M. L. M., Amorim, C., Araújo, A., Montenegro, M. C. S. M., Pena, A. and Delerue-Matos, C. (2013). Pilot monitoring study of ibuprofen in surface waters of north of Portugal, Environmental Science and Pollution Research, 20(4); 2410-2420.

Pranitha, A., and Lakshmi, P.K. (2018). Effect of pH on weakly acidic and basic model drugs and determination of their ex vivo transdermal permeation routes. Brazilian Journal of Pharmaceutical Science, 54 (2); 00070 .

Pravin, K.M., Sanjay, K.G. and Atul, K.M. (2018). Fate of pharmaceutical active compounds (PhACs) from River Yamuna, India: An ecotoxicological risk assessment approach, Ecotoxicology and Environmental Safety, 150; 297-304.

Samuel, F., Esayas, A., Raf, D. and Bart,V. B. (2018). Pharmaceuticals in freshwater aquatic environments: A comparison of the African and European challenge, Science of the Total Environment, 654; 324-337.

Sanderson, H., Johnson, D. J., Reitsma, T., Brain, R.A., Wilson, C. J. and Solomon, K. R. (2004). Ranking and prioritization of environmental risks of pharmaceuticals in surface waters, Regulatory Toxicology and Pharmacology, 39; 158-83.

Sándor, Z. J., Papp, Z. G., Kosáros, T. J., Hegedűs, R. and Csengeri, I. (2012). Potencial effects of pharmaceuticals and their residues in aquatic environment, Studia Universitatis “Vasile Goldiș”, Seria Științele Vieții, 22 (2); 247-255

Solomon, M., Grace, B., Brenda, M. and Patrick, N. (2015). Occurrence of selected pharmaceuticals in water and sediment of Umgeni River, KwaZulu-Natal, South Africa, Environmental Science and Pollution Research International, 13; 10298-308

Sosnowska, K., Styszko-Grochowiak K. and Gołaś, J. (2009). Leki w środowisku - źródła, przemiany, zagro żenia, Krakowska Konferencja Młodych Uczonych,

Stumpf, M., Ternes, T.A., Haberer, K., Seel, P. and Baumann, W. (1996) 
Nachweis von Arzneimittelrücksta“nden in Kläranlagen und FlieX gewa"ssern, Vom Wasser 86; 291-303.

Thomas, H. M., Nicolas R. B., Stewart, F. O., James, I. M. and Leon, P. B. (2018). A review of the pharmaceutical exposome in aquatic fauna. Environmental Pollution, 239; 129 -146

US Environmental Protection Agency. (2011). Method 1694: Pharmaceuticals and Personal Care Products in Water, Soil, Sediment, and Biosolids by HPLC/MS/MS. Pg. 1-77. December 2007.

William, J.D. and Randy, S. (1997). Groundwater Geochemistry:
Fundamentals and Applications to Contamination. CRC Press. SBN 9780873713085 - CAT\# L308

Wong, C.K., Wong, P.P.K. and Chu, L.M. (2001). Heavy metal concentrations in marine fishes collected from fish culture sites in Hong Kong, Archives of Environmental Contamination and Toxicology, 40; 60-69. 